\title{
What can be: Stakeholder perspectives for a sustainable food system
}

\author{
Jesus G arcia-G onzalez a* and Hallie Eakin b \\ Arizona State University
}

Submitted December 16, 2015 / Revised April 21, July 5, and November 9, 2016, and July 13, November 29, and D ecember 23, 2018 / Accepted D ecember 24, 2018 / Published online March 22, 2019

Citation: Garcia-Gonzalez, J., \& Eakin, H. (2019). What can be: Stakeholder perspectives for a sustainable food system. Journal of A griculture, F ood Systems, and C ommunity D evelopment, 8(4), 61-82. https:/ / doi.org/ 10.5304/ jafscd.2019.084.010

Copyright (C) 2019 by the Authors. Published by the Lyson Center for Civic Agriculture and Food Systems. Open access under CC-BY license.

\begin{abstract}
Any multistakeholder initiative that aims to build the basis for change in a food system, regardless of geographic scale, requires an understanding of what is important to stakeholders, how they view the boundaries of the system, and what changes they feel are needed. An assessment of stakeholder perspectives of the Phoenix Valley food system was conducted as an initial step in a process of food system coalition-building. The objectives of the research were to explore how active participants in the food system visualized a "sustainable food system" and to juxtapose their perspectives on food system sustainability with those in the academic literature to create an initial picture of food sustainability. Respondents emphasized the importance of education, local food, reducing

a* Corresponding author: Jesus G arcia-G onzalez, M.S., College of Letters and Sciences, Arizona State University, Mesa, AZ 85212 USA; +1-210-724-2485; jesus.garcgonz@ gmail.com

b Hallie Eakin, School of Sustainability, Arizona State University, Tempe, AZ 85281 USA; hallie.eakin@asu.edu
\end{abstract}

corporate power, and a strong desire to build a sense of community to better serve vulnerable communities. Nevertheless, the responses also revealed the difficulty of conceptualizing food system boundaries for intervention and the conflation of realist and idealist perspectives on what food systems are or could be. Stakeholders placed considerable weight on localism and the power of education and "demand constraint" on improving food system outcomes, while also attributing the root cause of Phoenix's problems to broader-scale structural factors that were outside of their control or capacity to influence. This case study describes the potential utility of conducting such preliminary

\section{Acknowledgments}

We would like to express our sincere gratitude to the individuals who participated in the interviews and everyone else who made this project possible. The study would not have been possible without the contributions made by Katherine Thompson-Ballentine, G eoffrey G oodwin, D eborah Namugayi, Sarah E. O as, Van Patterson, D aina Rasutis, and Christopher Robinson, all of whom helped to conduct and transcribe interviews. 
assessments in other cities, allowing stakeholders to reflect on their interests, agency, and capacities in the food system space prior to any efforts to build consensus and take collective action. We argue that this process is a crucial first step in any work on building alternative food systems, as it allows hidden areas of contestation (beliefs, values, goals) to arise. This enables participants to begin addressing differences and fostering trust, cooperation, and inclusiveness- thus ensuring the longevity of the coalition or group.

\section{Keywords}

Agrifood Movements, Food Assessment, Food System Planning, Local Food, Phoenix Valley, Stakeholder Perspectives

\section{Introduction}

The growing disenfranchisement and dissatisfaction of the current state of production systems, augmenting environmental degradation and increasing socio-economic inequality, have resulted in a call to action across cities in the Northern hemisphere. The right to culturally appropriate, just, and sustainably produced food has become the pennant of individuals and groups seeking to transform local food systems and to decrease their dependence on a highly globalized and unsustainable food system. Those engaged in food system planning across multiple scales, from local, regional, and national to global, have emphasized a range of central challenges and concerns for food system sustainability. These include climatic uncertainties, environmental degradation, social inequality, and the commodification of food (Foley et al., 2011; G odfray et al., 2010; Horlings \&Marsden, 2011; Tilman, Cassman, Matson, Naylor, \& Polasky, 2002). While there is a general consensus on the need for change from diverse perspectives, there is often less agreement over what issues should be prioritized for intervention (Eakin et al., 2016; Holt-G iménez \& Shattuck, 2011). The complex set of actors and activities that make up food systems at different scales and places, and the disparate meanings and values associated with the food system, make consensus nearly impossible along the appropriate pathways for improving food sustainability (Block et al., 2008). Any effort to improve food system sustainability must confront sustainability as a normative, value-laden concern, the idea that sustainability is based in both individual and collective ideas about what should be done and what the "ideal state" of the world should be. Assessments of sustainability need to grapple directly with the fundamental uncertainties that exist about what to sustain and thus where to focus interventions. These uncertainties are in part derived from the fact that different worldviews and values held by diverse individuals and groups will result in the prioritization of different aspects of system dynamics (Barthel, Parker, \& Ernstson, 2013; Block et al., 2011; Eakin et al., 2016).

Miller et al. (2014) argue that inquiry into the values that undergird sustainability initiatives is largely absent in sustainability science research and practice. They argue that making values explicit in sustainability transitions is critical for the effective societal deliberation of desired states, saying that "sustainability science research into the role of values in societal actions must be moved upstream in the research process" (Miller et al., 2014, p. 241). Sustainability science scholars have illustrated the importance of mapping out stakeholder perspectives in sustainability assessments and enhancing participation, not only to provide clarity in terms of visions and priorities, but also to highlight potential areas of conflict that may impede policy implementation (Reed et al., 2009; Spangenberg, 2011; van Kerkhoff \& Lebel, 2006). Such assessments can help illustrate gaps, assets, and opportunities in the food system. These assessments can enable food policy councils and coalitions (multistakeholder organizations formed at the local city or county level to inform local food policy) to more effectively meet stakeholders' needs. They can also serve as a baseline from which to measure the impacts that food policy councils have over time (Campbell, 2004; Harper, Alkon, Shattuck, HoltGiménez, \& Lambrick, 2009; Pothukuchi \& Kaufman, 1999). Ensuring dialogue and cooperation between those who produce knowledge and those who use it enhances the probability of success (Ingram et al., 2010). Stakeholder perspectives can also help illuminate the structure and fragility of the local food system, as well as help determine the individuals and organizations who 
play essential roles. The research presented here aims to help solidify what others have previously stated: that stakeholder participation is crucial in developing sustainable food systems because it provides a means for articulating conflicting perspectives, allows an exploration of the implications of such differences, and ultimately leads to a greater understanding (Pothukuchi \& Kaufman, 1999; Poulsen \& Spiker, 2014).

Urban centers are becoming arenas of both food system contestation and innovation in which varying viewpoints seek to effect change and set the ground rules for food system organization. Although there is a growing interest in and literature on local and sustainable food system alternatives, there is a gap in the literature as to how these movements and/ or processes begin to emerge and become active organizations capable of enacting local change (Bedore, 2014; Raja, Picard, Baek, \& Delgado, 2014). This case study focuses on the beginning stages of developing a food coalition or food policy council. This step could be argued as fundamental to building a sustainable local food system. Here we present the results of an effort to provide a group of highly engaged stakeholders ${ }^{1}$ with an initial assessment of the diversity of perspectives and associated values held by food system actors. O ur aim was to make the disparate perspectives on food system sustainability more visible in the planning process. At the time the research was conducted, these individuals were in the early stages of forming an organized food system coalition; no formal processes had been established (bylaws, values, mission, and vision), but a small group of food system leaders had emerged and was seeking funding for the formation of a food policy organization. O ur analysis is based on qualitative semistructured interviews with different actors in the Phoenix metropolitan area, focused on individual perceptions of the food system and its sustainability. The results highlight issues of agreement and potential avenues for intervention, as well as areas of significant ambi- guity - areas that may ultimately create challenges for effective food governance. Specifically, the study reveals a potential disconnect among stakeholders in terms of where they perceive that power is held within the food system, where they see their own agency in driving change, and what actions they feel are most significant to the goal of effecting food system change in the Phoenix Valley. We argue that making the landscape of stakeholder perspectives visible in these processes is an important first step in food system transformation.

\section{Setting the Table: A Conceptual Framework} Moving a food system onto a more sustainable pathway is essentially a challenge of governance and decision-making. In 2014, when these interviews were conducted, a group of highly involved individuals, representing all sectors of the food system, came together to discuss issues of emerging interest and potential localized solutions. The group has since officially formed the Maricopa County Food System Coalition, a small and active entity focused on four core values: (1) creating equal access to quality, affordable, and culturally appropriate food; (2) supporting the physical, mental health and well-being of all residents of Maricopa; (3) conducting responsible stewardship of natural resources, particularly of the unique desert ecology; and (4) empowering the community, embracing cultural diversity, and driving a vibrant economy forward. Forming a food system coalition delineates a space for social participation and action in which diverse actors can collectively define shared goals in order to enact local change.

In our analysis, we draw from O strom's (2011) Institutional Analysis and Development Framework (IAD) and Sabatier's (1988) Advocacy Coalition Framework (ACF) to explore stakeholders' perceptions and attitudes in the early stages of constructing the food policy coalition. These frameworks share an interest in collective action and institutional development, and have long been viewed as complementary (Cairney \& Heikkila,

\footnotetext{
${ }^{1}$ Since the research was conducted, a group of concerned and highly active Phoenix residents have created the Maricopa County Food System Coalition. They hold monthly meetings to discuss the current food issues in the metropolitan area, to build trust within active members and create a space where all perspectives are heard and respected. The coalition is now undertaking a formal food system assessment.
} 
2014). The ACF focuses on how policy coalitions change and learn. In particular, the ACF focuses on the beliefs that actors bring to such coalitions as they evolve (Sabatier, 1988). Sabatier's ACF posits that stakeholders form coalitions to influence a policy process via three fundamental belief systems that vary in degree of intensity: there are those who share a "deep normative core" (i.e., the hardest beliefs to change, reflecting an underlying personal philosophy), those with a "near policy core" (i.e., those based on causal perceptions and basic strategies on how to achieve a given goal), and those with "secondary (alternative) aspects" (i.e., the easiest of the three to change, those that can be redefined according to new information) (JenkinsSmith \& Sabatier, 1994; Sabatier, 1988). While a belief system will be affected by external factors (e.g., social and political changes), policy coalitions will tend to engage in "an ongoing process of search and adaptation motivated by the desire [of coalition members] to realize core policy beliefs. When confronted with constraints or opportunities, actors attempt to respond in a manner which is consistent with their core" (Sabatier, 1988, p. 151).

In contrast, the IAD focuses more explicitly on the "action situation" - the space in which diverse actors come together to form rules that will govern their collective activities. The IAD places less emphasis on belief structures, but acknowledges the influence of the attributes of actors who are participating in institutional development: their societal positions (the roles and responsibilities affecting their ability to influof Sustainability Goals ence change), their livelihood activities (and thus relationship to others and the resource base) and their world- views (a construct similar to that of "deep core beliefs" in the ACF) (Ostrom, 2011). Both frameworks acknowledge similar elements in policy processes: the attributes and/ or values of individuals and communities, the relationship of actors to resources (knowledge and social networks), social location (geophysical and socioeconomic), and the rules and norms that govern interactions (Barthel et al., 2013; Block et al., 2008; Block, Chávez, Allen, \& Ramirez , 2012; Born \& Purcell, 2006 Cairney \& Heikkila, 2014; Carolan, 2006; Colding et al., 2013; Holloway et at., 2010). We present a composite framework in Figure 1.

As posited by the ACF, the policy core and secondary or "alternative" belief structures of the individuals participating in a coalition are instrumental to how individuals ascribe to policy positions and strategies. These beliefs may be particularly relevant to how individuals will participate initially in a food policy coalition context given that they will inform ideas about what specific strategies and approaches are appropriate to change the food system. There is some research that provides the basis for hypothesizing what policy core beliefs the actors in the Maricopa food system might have, ranging from more conventional to more radical

Figure 1. Conceptual Framework of the Factors Influencing Stakeholder Perceptions

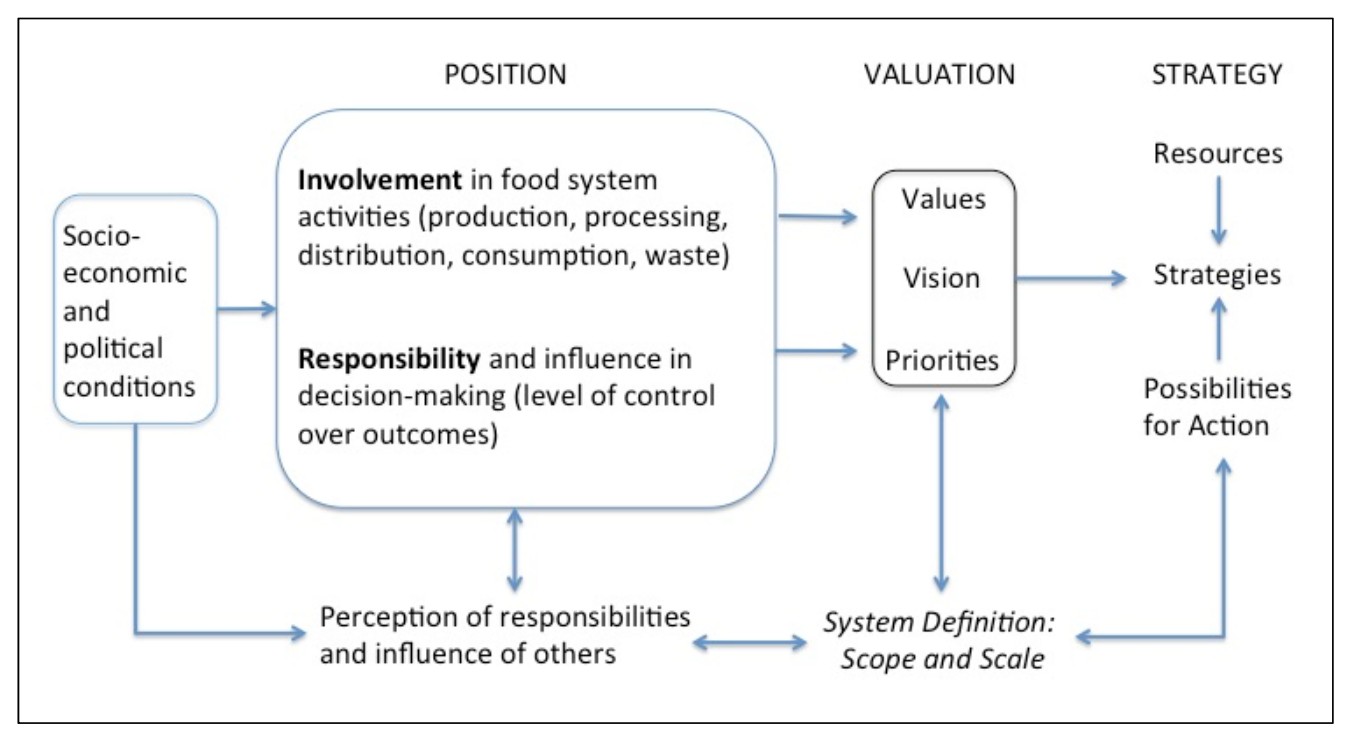

Note: Informed by Garnett, 2014; Ostrom, 2011; and Sabatier, 1988. 
ideas (e.g., G arnett, 2014; Holtz-Giménez \& Shattuck, 2011). G arnett (2014), for example, found that stakeholders' approaches to food system sustainability typically emphasize one of three different aspects of change, reflecting their differing values and priorities: efficiency, demand restraint, or food system transformation. Efficiencyoriented viewpoints support the idea that food sustainability issues can be addressed through technological innovation. Here the responsibility is placed on producers and supply chain managers to utilize environmentally friendly practices and techniques; the perception is that the problem originates from the misuse of scarce resources and that significant improvements can be made through improved management. In contrast, demandrestraint perspectives shift the "power to the people'" through an appeal to conscience, hoping consumers will halt excessive consumption and will opt to buy food products that have a "low impact." Finally, those arguing for food system transformation- what Holt-G iménez and Shattuck (2011) would characterize as a more radical position-posit that the problem is not about consumer choice or lack of technological advances alone, but rather of structural imbalances in the food system. This perspective sets forward the idea that environmental sustainability can only be achieved through structural changes. Each approach embodies a different "policy core" and secondary beliefs concerning the scale and scope of action needed. They also reflect different attitudes about the distribution of responsibilities for change and the food system activities that are most critical in driving sustainability outcomes.

As described in further detail below, our results illustrate that each of these diverse perspectives was present among stakeholders in the Phoenix metropolitan area; these general ideas about strategies for change are associated with differential perspectives on the locus of responsibility, different understandings about the scope and scale of the food system as a system, and the individual beliefs of particular actors. We use interview data to identify stakeholders' priorities and values associated with the food system; their perspectives on food system definitions and boundaries; and their specific ideas about entry points to food system transformation. This qualitative overview highlights opportunities for synergistic solutions as well as the complex tradeoffs that must be addressed to create and maintain sustainable food practices in the Phoenix Valley and elsewhere. Our aim is for this research to inform policymakers, organizations, activists, community leaders, and scholars who strive to engage the public in food system discussion and positive, sustainable change. Actors may use the information presented in this analysis to evaluate potential areas of conflict or issues of emerging consensus and as a means of understanding what concerns and issues motivate individuals to shape the food system.

\section{Methods}

Identification of Participants

On the premise that one's position and responsibility in food system activities at least partially informs one's values and priorities, we focused on individuals who self-identified (i.e., by volunteering to help organize the food policy work in Maricopa County), or were identified by others, as active in the Phoenix Valley food system. By purposely inviting individuals who are involved in different food system activities (see Ericksen, 2007, for a description of key food system activity domains), we intended to cover a range of positions and responsibilities that would likely influence differences in values, priorities, and ultimately normative ideas about policy strategies. Following Kloppenburg et al. (2000), our premise is that these individuals largely "account for most of the activity in the ongoing effort to transform our food systems. A definition of food system sustainability that fails to take their perspectives and standpoints into account is incomplete" (p. 180).

A list of active individuals participating in the initial meetings of the food group that later evolved into the food policy coalition was obtained from the group organizers. The list consisted of 79 stakeholders. Initially, those listed without an email and phone number were removed from the potential pool of interviewees. Those remaining were then stratified into categories based on individual self-identified roles (based on career fields or self- 
identified community involvement) within the food system (e.g., chefs, council officials, urban farmers, business owners, activists, farmers market organizers, nonprofit organizations, extension agents, and food bank representatives). O nce grouped by categories, a sample from each group was selected at random. The selected 36 stakeholders were approached via phone and/ or email and invited to participate in the survey; out of the 36 invited, 18 agreed to partake in the study.

The resulting sample was characterized by actors who more than likely would be active in some capacity in any future food system coalition work, as indicated by their involvement in the nascent food system group and their receptivity to participate in the study (given that the Maricopa Food System Coalition was not yet constituted at the time of the study). These stakeholders represented members of civil society and public service groups (food banks, extension agents, and public health officials) (5 of the 18), independent activists (4/18), policy officials (3/18), producers (3/18), waste management representatives (2/18), and a retailer (1/18). While their perspectives cannot be said to be representative of Phoenix residents in general, they are indicative of individuals who are already actively engaged in influencing food system development in the area.

Semistructured interviews were conducted in person or by telephone and generally lasted 30 to 45 minutes. Interviews were recorded, transcribed manually, and then the responses were coded for each question according to recurring themes emerging from the data (Bernard, 1994). Each participant was interviewed individually and was not given additional information beyond the provided questionnaire. This insured that the answers of each stakeholder would accurately reflect their unique perspective. Following our framework, the interviews focused on questions pertaining to the interviewee's position and responsibilities in relation to the food system, their conceptualization of the system boundaries, their specific vision of sustainability, their primary concerns in achieving a sustainable food system, and what interventions they felt should be prioritized.

\section{Results}

Stak eholders' Roles in the F ood System We hypothesized that the stakeholders' different perspectives on the food system would depend in part on their specific position within the system and their associated beliefs and responsibilities. In an effort to determine the degree of influence one's positions has on people's beliefs and actions, we asked interviewees to describe what food activities they were engaged in and their responsibilities in those activities. The interviewees volunteered activities that represented both supply chain activities associated with their positions in the food system (e.g., food production, processing, and distribution), as well as specific domains on which the stakeholders perceived themselves to have responsibilities and influence (e.g., education and community building).

Not surprisingly, each stakeholder's primary occupation (Table 1a) and associated mandates (Table 1b) had a strong influence on their activities within the food system. For instance, those individuals in civic service and policy officials (8/ 18) were the only ones to raise the importance of policy development. However, besides the expected occupation-activity correlations, we discerned two additional patterns. All of the interviewed stakeholders were involved in "cross-pollination" by participating in at least two of the 11 food system activity categories; that is, they often reflected interests and perceived responsibilities beyond the scope of their primary occupation. A few actors were even involved in four or more food system activities as part of their professional and private lives. Second, certain activity categories can be considered cross-cutting interest domains, such as education (10/18), community building and food associations (9/18), and program and project development (9/18). Given the number of respondents who identified with these types of activities, it is clearly essential that food system analysis incorporate domains of action and responsibility beyond the traditional activities associated with the food supply chain. 
Journal of Agriculture, Food Systems, and Community D evelopment ISSN: 2152-0801 online

https:/ / www.foodsystemsjournal.org

D efining a F ood System

A common tension in any sustainability governance initiative is defining the nature of the system

Table 1a. Stakeholders by Self-Identified Career

\begin{tabular}{|c|c|c|c|c|c|c|}
\hline & \multicolumn{6}{|c|}{ Career affiliation } \\
\hline & Civic Service & Activist & Policy Official & Producer & Waste Mgmt. & Retail \\
\hline 1 & $x$ & & & & & \\
\hline 2 & $x$ & & & & & \\
\hline 3 & $x$ & & & & & \\
\hline 4 & $x$ & & & & & \\
\hline 5 & $x$ & & & & & \\
\hline 6 & & $x$ & & & & \\
\hline 7 & & $x$ & & & & \\
\hline 8 & & $x$ & & & & \\
\hline 9 & & $x$ & & & & \\
\hline 10 & & & $x$ & & & \\
\hline 11 & & & $x$ & & & \\
\hline 12 & & & $x$ & & & \\
\hline 13 & & & & $x$ & & \\
\hline 14 & & & & $x$ & & \\
\hline 15 & & & & $x$ & & \\
\hline 16 & & & & & $x$ & \\
\hline 17 & & & & & $x$ & \\
\hline 18 & & & & & & $x$ \\
\hline Total & 5 & 4 & 3 & 3 & 2 & 1 \\
\hline
\end{tabular}

that is to be governed (O strom, 2011). Any effort to improve a local food system will depend on the compatibility of different actors' ideas of what the system is, what it includes, and what it does not. The majority of the interviewees responded the question, "What is a food system?" by invoking the ideas of a closed loop system, incorporating the primary activities of the food supply chain (an interconnected structure encompassing everything from production to waste disposal). Some respondents (civil organizations, waste management) saw the system as being locally embedded: "a closed loop, having a circular structure, with local farms." However, most respondents described it more abstractly: "Everything is a web. We have to provide collective food for everybody." These responses reflect two ways of considering the meaning of a food system; the first way constitutes a

Table 1b. Stakeholders by Perceived Areas of Interest, Influence, and Involvement

\begin{tabular}{|c|c|c|c|c|c|c|c|c|c|c|c|}
\hline & \multicolumn{11}{|c|}{ Domains of Interest, Influence, and Involvement } \\
\hline & Education & $\begin{array}{c}\text { Community } \\
\text { Bldg. }\end{array}$ & $\begin{array}{l}\text { Program } \\
\text { Develop. }\end{array}$ & Production & Distribution & $\begin{array}{c}\text { Policy } \\
\text { Develop. }\end{array}$ & Retail & $\begin{array}{c}\text { Food Bank } \\
\text { Charity }\end{array}$ & $\begin{array}{l}\text { Waste } \\
\text { Mgmt. }\end{array}$ & $\begin{array}{l}\text { Monitoring/ } \\
\text { Enforcement }\end{array}$ & Processing \\
\hline 1 & $x$ & $X$ & $\mathrm{x}$ & & $x$ & $x$ & & $x$ & & & \\
\hline 2 & & $\mathrm{x}$ & $X$ & & & $x$ & & & & & \\
\hline 3 & $\mathrm{X}$ & $X$ & & & & $x$ & & & & & \\
\hline 4 & $\mathrm{x}$ & & $X$ & & & $x$ & & & & & \\
\hline 5 & & & $\mathrm{x}$ & & $\mathrm{X}$ & & & $\mathrm{X}$ & & & \\
\hline 6 & $\mathrm{x}$ & & & $\mathrm{X}$ & & & & & & & \\
\hline 7 & $\mathrm{x}$ & $X$ & & & & & $x$ & & & & \\
\hline 8 & $X$ & $\mathrm{X}$ & $\mathrm{X}$ & & & & & & & & \\
\hline 9 & & $X$ & $\mathrm{X}$ & & & & & & & & \\
\hline 10 & & & & $\mathrm{X}$ & & $\mathrm{x}$ & & & & & \\
\hline 11 & & $X$ & $X$ & & & $x$ & & & & & \\
\hline 12 & $X$ & & $X$ & & & & & & & $X$ & \\
\hline 13 & & & $X$ & $X$ & $X$ & & $X$ & & & & \\
\hline 14 & & $X$ & & $x$ & & & $x$ & & & & \\
\hline 15 & & $X$ & & $X$ & $X$ & & & & & & $X$ \\
\hline 16 & $X$ & & & $x$ & $X$ & & $X$ & $X$ & $X$ & & \\
\hline 17 & $X$ & & & & & & & & $X$ & & \\
\hline 18 & $x$ & & & & $X$ & & $X$ & & & & \\
\hline Total & 10 & 9 & 9 & 6 & 6 & 6 & 5 & 3 & 2 & 1 & \\
\hline
\end{tabular}


focus on the nature of existing food activities in particular places and the relationship among specific activities (e.g., production, waste, distribution); the second invokes the normative meaning of a "systems" framing for food in terms of what it should look like or what it should accomplish (e. g., connections, health and nutrition, collective food, cyclical structure). While some stakeholders perceived a food system to be associated with the resource context of food activities, others emphasized the social and institutional elements of a food system. In this vein, some stakeholders described a food system as, for example, the "people and processes" of those "who have a say in how [food] is grown and distributed" and the social connections and the "nexus of programs and policies" that taken together ensure food access--e.g., the "connection of consumers, producers, distributors, and a nexus of programs, policies that come together to make sure people have access to food."

\section{Perceived Boundaries of a F ood System}

It is not only the content of a food system that is in dispute in any attempt to intervene and manage system change, but also how system boundaries are perceived. The responses revealed that system boundaries can be perceived to be geographic in nature (e.g., "Phoenix metro area," "National," or defined by climate conditions). System boundaries can also be defined by social, biophysical, or economic networks and institutional processes (e.g., "imports and exports" or "resource cycles"). Respondents accompanied perspectives with critique, reflecting their normative beliefs and ideas about what the boundaries of a food system should be while recognizing that current systemic conditions were not ideal.

Prominent in the stakeholders' responses was a concern over the large geographic expanse of the Phoenix food system, as well as the commercial and industrial nature of the food supply and its distribution in Phoenix. They commented on the "big grocery stores and big box stores," the large distances that food is traveling, and the predominance of "massive distribution and massive transportation." A participant stated that "most food comes from thousands of miles away, about 1,500 miles" and highlighted the need for a "local nutrient cycle."

This perspective was not just related to food moving into the region for consumption. O ne stakeholder commented on how much of the food produced in Arizona is exported:

I think of local food. I describe boundaries as not set, permeable and changing...[The] unique thing about Phoenix system is the amount of food that is grown here but is exported elsewhere. Arizona is an Ag state, but most of it leaves the state. - C ivil

Organization

While recognizing the long distances and economic networks that are embedded within Phoenix's food system, most interviewees indicated that this sprawling structure was undesirable and that a more geographically bounded system would be preferred. Current boundaries (a mixture of local, national, and globally connected systems) were "inadequate" and "flawed," threatening food security with an imbalance of locally produced versus imported food:

It's as generic as can be because stuff has to come from elsewhere. Unbalanced. - R etail

Inadequate. Flawed. If food stopped coming to the city, we would have three days of meals...If only $30 \%$ of Phoenix residents were growing their own food it would be better. A ctivist

Nevertheless, some respondents noted that in some areas (e.g., desert areas) it "no longer makes sense" for food to be grown. Others, particularly those stakeholders involved in retail and distribution, considered the boundaries of the Phoenix system to be fairly "generic" and noted, "stuff has to come from somewhere." In contrast to a focus on geography, material, and economic flows, some stakeholders from civil organizations emphasized the interaction of social needs, barriers, and physical boundaries in defining the food system - including economic disparities, health problems, land and tenure access inequalities, as well as economic and policy 
restrictions for producers in terms of possible pathways to consumers.

In every food system there are a number of things that have broken down, from low pay to farmers to no access for the ones that need it. ... Every food system is different, with their own problems.... Some of the issues that come to mind [here] are water - the need and availability, property rights ownership, issues that make use of land for agriculture in Phoenix more difficult due to politics and residential developments. Not a lot of support or sympathy for folks that aren't able to afford a healthier diet and for making "poor choices" - looking down on people that have barriers. The anti-undocumented sentiment dampens families with young children from accessing healthy, nutritious food. - C ivil 0 rganization

Regardless of the perceived extent of system boundaries, most of the interviewees perceived that their influence on the system was largely confined within a radius of 150-250 miles (240-400 kilometers) around the city. O ther policymakers, like producers, also expressed concerns over food system self-sufficiency. They drew attention to a perceived lack of shared perspectives by different stakeholders about food systems and their boundaries, arguing that this produces "no cohesion [and] no preferred outcomes."

\section{E nvisioning a Sustainable F ood System}

Some agreement on what the desired state of a system should be is fundamental to any collective effort for sustainability analysis. The responses to the question "What is a sustainable food system to you?" were varied, invoking outcomes such as "improved nutrition," "improved access/ distribution" or "social equity and justice." Responses also invoked mechanisms perceived to be instrumental to such outcomes such as "education," "local food activities," "organic/ alternative farming methods" and "resource conservation" (Figure 2). The most prominent themes were the relationship of local food activities to social equity and justice, and the need for food activities and

Figure 2. Desirable Characteristics of a Sustainable Food System According to Stakeholders

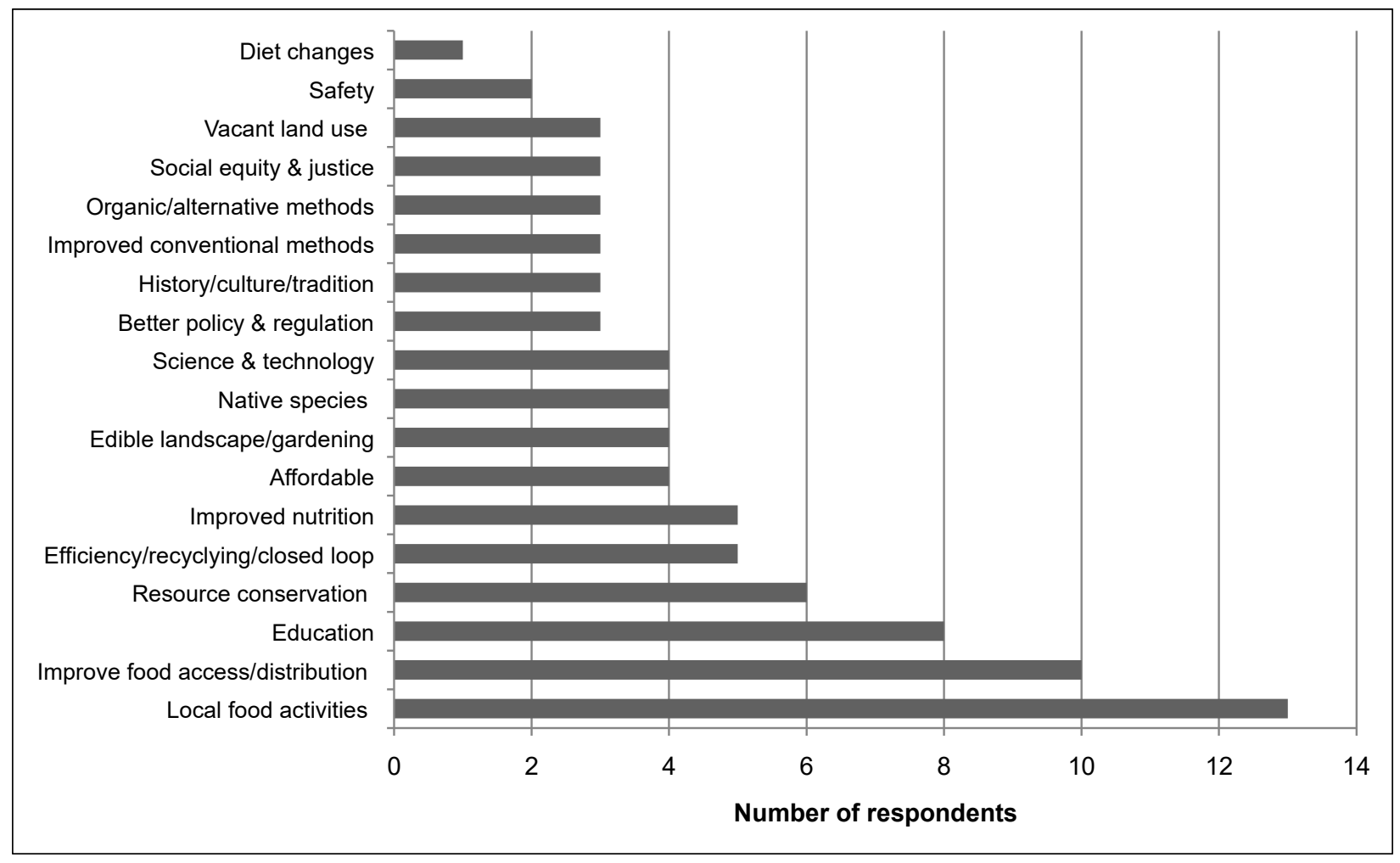


diets to better reflect the environmental constraints and opportunities of the urban region:

There are currently 900 thousand people in AZ who do not get enough to eat, $15 \%$ elders. ... [We need] community food systems- where people are able to access healthy, nutritious, culturally appropriate food that has been produced in a just way ALL time. - Civil Organization

How do we get distribution to those most vulnerable and which need it the most? For example where are the farmers' markets? Not in low-income communities, they are at places where people have access to healthy quality food. Rebranding the term from farmers markets to something more accessible - to make it more appropriate and affordable - to encourage the use of food stamps. - Civil 0 rganization

O thers incorporated self-production and urban landscape changes as part of what constitutes a sustainable food system:

Edible landscapes that have appropriate plants for our environment. - A ctivist

We need to change our diet to a diet that is based on food that grows in desert environments. - Policy/ Regulation 0 fficial

More people growing their own food or buying from local farmers, or just more included in decision processes. Transparency. - Civil O rganization

The number of interviewees who echoed the above sentiments, and the passion in which these opinions were expressed, speaks to a general discourse in which the local food movement is positioned as the savior of food in the United States and elsewhere. Stakeholder suggestions on how to realize the vision of local food were varied. Suggestions included introducing zoning policies that enable urban farming, reclaiming vacant lots, educating citizens about cultivating their own food in their backyards, creating a seed bank, facilitating the preservation and sharing of seeds, and allocating resources that support local small producers and create local jobs. Most of the respondents echoed the need for a sustainable food system to address multiple functions and needs. As one participant put it:

A system that is not so heavily focused on just economic outcomes, that allows for better environmental and social outcomes (more subsidies so that farmers can improve livelihood, and offset the economic costs of growing things in a more environmentally responsible way). ... Allowing for adaptive diets that [are] regionally appropriate. - Civil o rganization

One stakeholder delineated a list of factors necessary to have a truly local sustainable food system:

Sustainability is a stop gap measure, what we mean by sustainability is to further sustain what we are doing. . . . How do we design regenerative systems? There are seven parts: 1) education, 2) create farmers, 3) local seeds, 4) culture (policy, etc.), 5) value added products, 6) collection \& distribution, and 7) alternative farming methods. When all these are working, we will have a thriving system. - A ctivist

Nevertheless, the majority of the stakeholders viewed the possibility of creating a sustainable food system in the Phoenix valley as a huge undertaking. This was implied by the language used to address the question: "very radical," "challenging," and "doubtful."

Challenges to A chieving a Sustainable F ood System Stakeholders were asked what they viewed as the major challenges for achieving a sustainable food system. In aggregate, they identified 13 areas of concern: education, problems with successful collaboration and follow-through, corporate power, policy and regulations, food deserts, waste, misconceptions about the taste and price of healthy food, 
social (in)justice, monocropping, local food exports, environmental degradation, lack of infrastructure, and industrialization (Figure 3).

According to stakeholders, the greatest barrier to achieving a sustainable food system is the lack of childhood education programs, particularly those that emphasize direct connectivity to sources of production and the experience of production (rather than, for example, nutrition per se). They expressed that these programs could teach children about our food production in order to help them connect to the food chain and empower children to make a difference:

[Kids] don't even know what plant they are looking at. ... If we got our young people properly educated on how to grow edible landscapes to take responsibility and empower themselves. - A ctivist

Every school should have a school garden.... For people to be in touch with their food we need to start with the kids. I would hate to give up on adults, but there is a lost generation of people who think food needs to be fast food. - Producer

Stakeholders also mentioned the importance of educating local people, citizens, tourists, and stakeholders as a means of reinforcing sustainability efforts.

Everybody [is] set up to survive off the mega supermarkets. It is designed around the idea of "how do I provide more for less money."... It should be "this is my health, this is what I'm living off. ... We can educate people and give them the ability to find that resource. - A ctivist

A system that educates not only local people but also tourists, to show them that we can grow the food here in this dry state but that we also can distribute in an eco-friendly way

Figure 3. Challenges to Achieving a Sustainable Food System in the Phoenix Valley

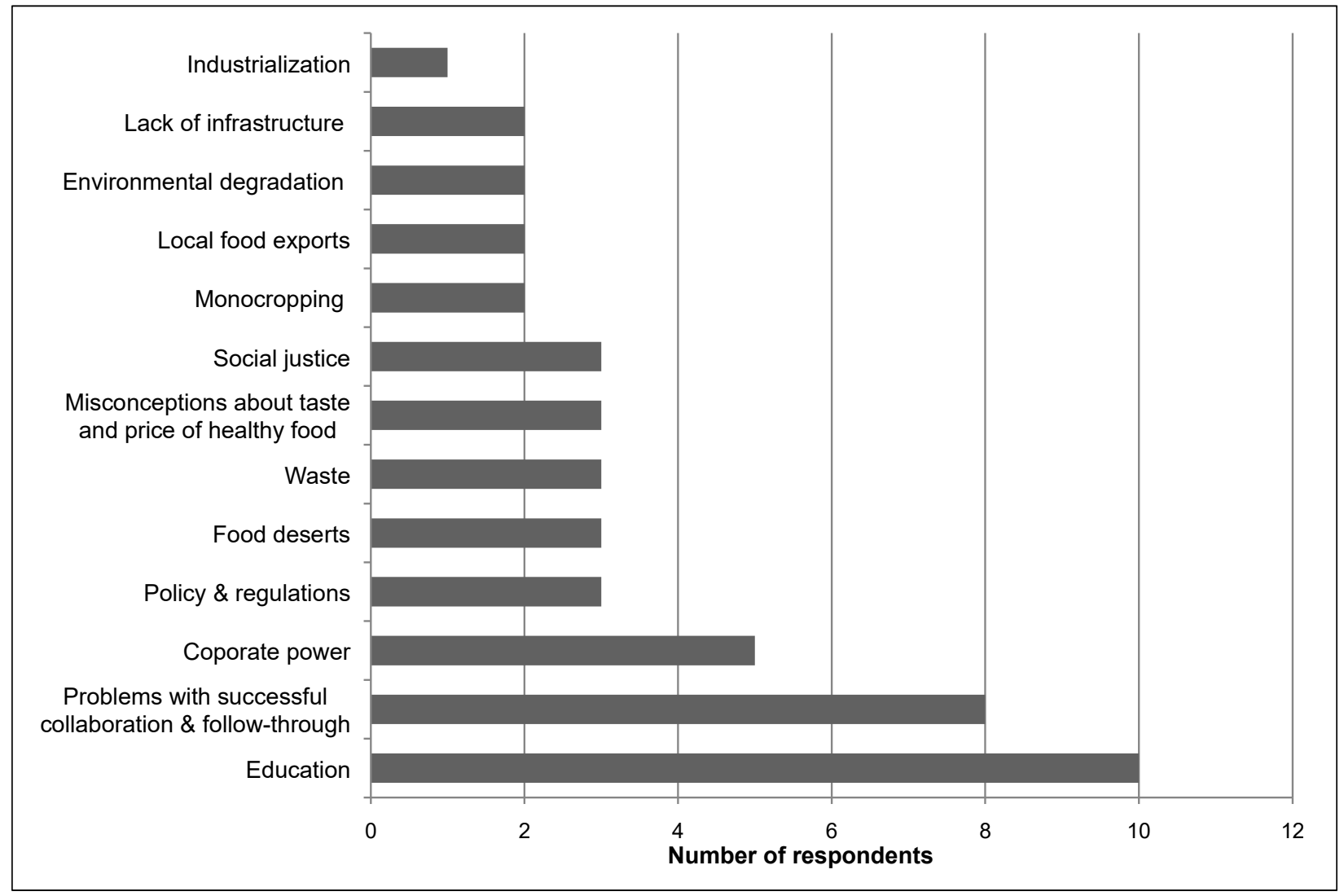


and then finally recycle it. - W aste $\mathrm{M}$ anagement

Successful collaboration and follow-through were understood as the involvement and collaborative work of various stakeholders with a common goal, where the work is continued over time. Stakeholders perceived this to be difficult to achieve in Phoenix:

People don't know how to work together. ... If it's not their idea, to hell with that! - A divist

Meetings that I go to - the people are far removed from the people they are trying to serve. Largely they have a class privilege talking about poor people's food access. ... [Meetings] are not conducive to people participating. - Civil O rganization

[What is needed is] having a good core group that understand each other and sees eye to eye with the goals. - A ctivist

Several of the participants mentioned corporate control as a problem with the current food system and a barrier to sustainability, and linked this issue with the need for improved consumer education.

Factory farming is all about big money and profit and the only way we're going to change that is with our feet and our votes; consumers need to vote with their purchasing power. Maybe the most important thing we need to do is try to educate I guess. ... It would be nice to get better information presented in a fair and impartial way so people could get an idea of the value of taking control of their own health by eating better and being more mindful of the food choices they make.

- Produœr

Of the eight stakeholders directly involved, to varying degrees, in public service and policy, only three pointed out the importance of local, state, and national policy and regulations in achieving food system sustainability. They expressed that policymakers should focus on making changes in the bigger system as well as over the long term.

The day-to-day work everyone at different agencies are doing is great but they don't provide long-term policies! [What is needed is ... .] a food council that takes a problem and resolves it, then moves to the next issue. O ne that creates effective policy and programs.

- Civil 0 rganization

We need policy changes, that comes through elections. - Civil 0 rganization

$\mathrm{V}$ alues to preserve from the ex isting food system In an effort to assess what stakeholders valued in the existing system, we asked participants if any aspects of the current food system should be preserved. Interviewees emphasized the growing food movement in Phoenix as enabling positive developments recognizing greater support of farmers markets, community supported agriculture (CSA), and community gardens. They also emphasized the incorporation of orphan crops and technologies that preserve and enhance ecosystem services, efforts at increased cultural preservation, individual empowerment, and innovative programs that support urban agriculture and food education.

Many respondents suggested that the demand for change in the system is already evident in the increasing activity they have noticed at farmers markets, CSA programs, and community gardens, as well as the overwhelming support for these programs from consumers and government officials:

There are exciting programs coming up such as Phoenix Renews, which utilizes public abandoned/ unused lots to make something useful for the communities, gardens, parks. ... County extension agents teaching nutrition education classes ... Local agricultural production programs that provide support to producers. - Civil Organization

D espite the generally enthusiastic support of existing avenues of direct marketing and local production, participants also indicated contradictory 
feelings toward the overall functionality of farmers markets. They also urged restructuring them to make sure the markets are healthy, accessible for everyone, and inclusive of all cultures represented in Phoenix:

Farmers markets have lots of junk- jams and jellies and butters and really "shit" food. It's not healthy. It's all dependent on the agricultural legacies of colonialism. - Producer

O thers emphasized diversity as one of the greatest strengths the Phoenix Valley has to offer, representing an untapped resource that needs to be incorporated in the local food movement:

We should learn from and embrace the past [Native American traditions] as well as celebrate it. - Policy/ Regulation 0 fficial

There's underground things going on, but they are [all] separated. . . . Cultures should feed off each other, make each other stronger, celebrate each other. - A civist

Transitioning to a sustainable food system Respondents overwhelmingly emphasized a need to start the development of a sustainable food system with an investment in the social dimensions of the system through empowerment, improved communication, collaboration, and common understandings of challenges and solutions.

There's so much you can do on a local level by reaching and bringing people together with common interest and cooperating, whether it be through leveraging your buying power. - Producer

Understanding what is there! Something that can be a blessing and a curse if the number of folks that are trying to change the system. They are easy to identify, but if we could only get them on the same place and get them to work together. - Civil Organization

There are so many people that have built up perceived ways on how the system should function, but they should take a step back and see what is REALLY going to make the biggest impacts and where we'll benefit. ... How do we get everyone together and figure out what we really want? - A divist

In creating a sustainable food system, others stressed the need to organize individuals into a food policy council to "get things done." However, several expressed caution as to how big any one organization should be in order to actually achieve their goals and move forward. For example, one interviewee stated, "trying to get people together to form a local food coalition is the hard part. People cannot work together, working at a grassroots level, teaching farmers, getting farmers to grow their own food and share it; community is feudal, when it comes to getting things done, egos get in the way!"

Respondents advocated for educating the public, especially youth, for a deeper understanding of food production, policy, injustices, and resources and opportunities that are available. This deeper understanding would include improving our "relationship with food" by strengthening our knowledge of where food comes from and how its cultivation can affect our bodies via nutrition.

I would create a growing smarter program with teens to make cities implement urban boundaries that would encourage less lawns and more gardens. Education is key to everything. - Policy/ Regulation 0 fficial

Educate the public about the food policy council, get the people's perspectives on what issues need to be addressed. Apply a just governance system - who sits at the table? Who is represented? We need to get everyone on the same page, not only speaking but understanding the same language. - Civil Organization

We can combat food insecurity, educate the public on "what health looks like." - Civil Organization

Respondents also emphasized improving 
resource efficiency through technological innovations and resource management strategies. Strategies to improve resource efficiency included microdrip farming systems, improved land use (i.e., more gardens and fewer lawns), and reducing food waste.

Identify available arable land for farmers, set up a system to reduce water costs. - Civil O rganization

We should start with recycling food waste! We need to take food waste to food desert, school, community gardens and break it down there and educate locals about the value of food. - W aste $\mathrm{M}$ anagement

Lastly, several interviewees suggested the need to empower people and create a more "just governance system." Empowerment was thought to be possible through increased self-sufficiency in production as well as through more inclusive governance. Their ideas reflect the need to create "social spaces" where food acts as a mechanism for social action (i.e., Feenstra, 2002).

Community organizing for collective power for long term instead of short term service approach. - Civil 0 rganization

Bring everyone into the conversation and get them involved, create ownership for everyone and make them feel what they are contributing make a difference, which it does.

- Policy/ Regulation 0 fficial

Influential actors in the Phoenix food system

The willingness of any actor to get engaged in the process of system change is not only a function of how he or she views his or her own responsibilities and self-efficacy, but also how he or she views the influence and responsibilities of others ( $G$ rothmann \& Patt, 2005). When asked what actors had the greatest influence on the local food system, most respondents perceived national political and corporate actors to have the greatest influence and power.

I firmly believe that politicians no longer have the power to do anything because the corporations really have the power. - A divist

I think the dominant players in the Phoenix food system are not people in my circle, they are people in big leather chairs behind a big desk, behind a big corporate office. - Producr

The big business. They drive a lot of what people are eating, are controlling what [people] have access to. - A ctivist

City and state actors and local consumers were perceived to be relatively less influential in the system, although some expressed hope that consumers could be empowered to create change.

Consumers and definitely policy makers (they are the one that need to be approached, people working at the city and state). Y ou can buy products at farmers markets but there needs to be policies and programs that make it possible for change to occur at a larger scale. - Civil O rganization

Money is the power. You vote with your dollars. Consumers have the power potential to lead change but are at times unwilling to change. - A ctivist

[Consumers] have the numbers. When enough people get behind the movement, Phoenix citizens have to grow at home instead of buying groceries. After year one, they realize they can plant a seed that costs almost nothing and get a whole plant and do not have to buy groceries. This will empower the people. - A ctivist

\section{Discussion}

The Advocacy Policy Coalition framework is premised on the idea that individuals who become involved in systemic transformation via politics (i.e., policy councils or coalitions) are moved by their desire to convey their beliefs, values, and ideals into policy (Sabatier, 1988). Researchers working with the Institutional Analysis and D evelopment framework also highlight the 
importance of the different value sets and priorities of stakeholders, as influenced by their positions and associated activities, and how these influence any "action situation" (Ostrom, 2011). Food policy coalitions and groups are, in their essence, initiatives to create spaces for collective action; thus, it is important to assess the starting positions and perspectives that disparate actors bring into these arenas to give shape to the processes of change that follow. To date, most academic attention on food policy councils and coalitions has been in the frame of evaluating their value and structure in urban planning (Pothukuchi, 2004; Pothukuchi \& Kaufman, 1999), the challenges they face, and their abilities and limitations in enacting change (see, for example, Allen, 2010; Barthel, Parker, \& Ernstson, 2013; Bedore, 2014; Colding \& Barthel, 2013; DeLind, 2011; Harper et al., 2009; Holloway et al., 2010; Schriff, 2008; Slocum, 2006). Pothukuchi and Kauffman (1999), for example, were early advocates for incorporating food system assessments and agendas into traditional community planning. Stakeholder perspectives and their congruence or dispersion around food system objectives are less addressed in this literature, although they are often recognized as important. For example, in a study of collaboration around Baltimore's food system governance, Bedore (2014) found that collaboration was partially attributable to the ability of such groups to identify both a use value and an exchange value in food system initiatives, as well as their ability to draw on "civic capital" - i.e., shared identity and trust tied to place. As Raja et al. (2014) describe, the planning community has advanced in embracing many concepts and approaches to food system innovation over the last decades. Nevertheless, there is a risk that the engagement of planning and policy in local food issues will not be sufficiently reflexive, critical, and transparent to address grassroots interests and agendas (Raja et al., 2014). For example, Raja et al. (2014) analyzed food system change in Buffalo, New York. Their analysis found that two of the seven factors they associated with productive, progressive change reflected the advantage of a shared history of food system practice. They also reflected a common vision among the "radicals" who were participating in the city's efforts for food system change. Nevertheless, we often know less about how diverse individuals in the city come together to create the common visions that eventually prove instrumental for food system change (Bedore, 2014).

There is also relatively little focus on the degree to which the perspectives and beliefs held by individuals were divergent prior to any formal activity of coalition building and system change (Marin, Ely, \& van Zwanenberg, 2016). Knowledge of the range of perspectives prior to forming a coalition not only can serve as a baseline for understanding any subsequent convergence in perspectives, but also can serve to evaluate what viewpoints over time become less dominant or may have been marginalized in policy processes. Assessing the diversity of visions and viewpoints of individuals prior to any collective process may also allow such individuals to freely verbalize their motivations, goals, and vision for their food system. Moreover, it allows them to do so independently of their social position or ability to influence others. As Hoey and Sponseller (2018) noted, tensions between those sitting at the table are the main barriers to successful and long-term change - tensions that have already been noted by the interviewees in this study.

It was evident from the interviews that the values, ideals, and beliefs, as well as positions, social networks, and associated activities of the interviewees, help shape their modes of action, behaviors, and idealized views on what a sustainable food system should be. This diversity of viewpoints, however, is not necessarily a detriment to any emergent coalition. If a coalition can form with principles of inclusion and equity, it can generate significant value and have potentially greater leverage in effecting food system change (Block et al., 2008; Carolan, 2006). O ur study provides some initial insights into these issues and potentially identifies some critical areas where thinking about mechanisms for cross-scalar change may need to be enhanced.

The C urrent F ood System

While many stakeholders perceived a need for structural transformation in order to achieve sustainability, their conceptualization of the food system conflated realist and idealist perspectives. 
Interviewees recognized the strong influence of supply chain structure, national and transnational commercial actors, and national policy on current processes and outcomes; however, their response was to envision a system with a strong place-based center, characterized by grassroots initiatives and capacities for change. This is not surprising as the actors participating in this study were those with geographically local mandates, roles, and responsibilities. Their perspectives epitomize the complexity of food system change; that is, there are numerous elements of the multiscalar, interconnected food system that are perceived to be exogenous and out of the control of local actors, and these elements are often perceived to be the most important and instrumental in driving food system outcomes. Nevertheless, actions to transform systems that do not explore how to effectively engage with these actors and larger-scale processes may ultimately be only partially effective (Allen, 2010).

\section{Food System D ynamics and Boundaries}

Insights from Institutional Analysis emphasize the importance of defining system boundaries. These insights also emphasize cross-scalar institutional influences on system dynamics in any initiative to govern a shared resource (O strom, 2007). The interviewees had wide-ranging ideas about what constitutes a food system, what might be considered to be the boundaries of the food system, and the organizational levels at which food system responsibilities reside. For example, the concept of "community" arose as an integral part of a sustainable food system, yet the scale and scope of "community" were not clear. While the food system was often defined in terms of "local" social and environmental interactions, these interactions were typically idealized and abstract. Underneath the emphasis on community was also an implicit assumption that greater "closeness" and proximity would enhance equity within the system, although this assumption has been challenged in the literature (see Allen, 2010; Born \& Purcell, 2006; D eLind, 2011). Many respondents reflected some of the aspects of Winter's (2003) concept of "defensive localism,"-- i.e., a reactive ideology in which local must be better in the face of the perceived negative externalities and politics associated with the globalized food economy. Scholars have pointed out the importance of connecting activism and policy, arguing that community members, activists, and government entities can work toward institutionalizing sustainable food systems efforts through local policies (Allen, 2010; Campbell, 2004; Feenstra, 2002; Pothukuchi, 2004;

Pothukuchi \& Kaufman, 1999). As many scholars have argued, local may be the solution to some of the challenges in the food system. However, it is often the case that local is a (poor) proxy for more complex and implicit concepts of empowerment, identity, and social embeddedness (Winter, 2003).

E ssentials to A chieving a Sustainable F ood System A majority of the interviewees insisted that education - particularly that of consumers- is absolutely critical to the development of a more sustainable food system, demonstrating the belief that it is through individual actions (i.e., "voting with your dollar") that widespread change materializes (e.g., G arnett's [2014] "D emand restraint"). Some stakeholders believed that in order to enact long-term change there is a need to start early, for example by establishing garden programs in schools to teach kids how to grow their own food and appreciate healthy products. Others spoke on the need to educate residents about growing their own food in their backyards and about making "healthier" food choices, emphasizing experiential and affective education over information dissemination. The emphasis on experiential education implies that respondents felt that solutions to the challenges preventing food system sustainability already exist. It also suggests that respondents felt that new technologies or knowledge are not as critical as educating people about existing information and solutions and motivating them to action. This focus on education echoes the priority action around which many existing policy coalitions have concentrated their efforts (Schriff, 2008; Sherb, Palmer, Frattaroli, \& Pollack, 2012). This underscores the finding that education is an area where local food actors perceive they have agency and influence. However, this focus on individual actions and the approach of voting with your dollars tends to favor more affluent individuals with access to the resources needed (e.g., money, 
time, and transportation) to change their modes of action and consumption, motivated by pressure from their social networks, the acquisition of new knowledge, and their subscription to social trends (Ericksen, et al., 2010; Guthman, 2003; Guthman, 2008).

Local food production and direct marketing were strong components of the participants' visions of a sustainable food system in the Phoenix area, reflecting a more structural-transformation perspective on sustainability (Garnett, 2014). Stakeholders concurred that there was a need for a greater focus on programs and projects promoting local production and marketing (e.g., farmer markets, gardens, nutrition classes, etc.) as the initial steps in transforming the system. Many of the respondents saw corporate power as a hindrance to a more sustainable system. They saw the connection between corporate influence and governmental regulation as part of a larger power structure imbalance that could be remedied with increased local ownership and control. Given that many of the respondents were involved in local production, policies, and activism, this result is not surprising. Their perspective also reflects an important general trend that increasingly embraces localization as the tonic for the ills of the global food system (D eLind, 2011).

Possibly reflecting the early stage of the policy process (given that the policy coalition was not yet formed when we conducted this assessment), very few of the interviewees focused on policy and regulations - in other words, the formal institutions of the food system--as points of intervention for achieving a sustainable food system. Presumably, once the stakeholders were formally participating in a defined "action situation" in which they had acknowledged roles in governing the local food system, specific policies and formal public programs would become subjects for intervention (Raja, et al., 2014; Scherb et al., 2012).

The lack of attention given by the interviewees to local and state policy and regulations may also reflect the general perception conveyed by the interviewees that the food system is currently dominated by actors and entities that are geographically distant from the Phoenix area and by (unregulated) market transactions. D espite the recognition of a need for a more structural transformation, interviewees tended to focus on nongovernmental action and grassroots change. Still, one stakeholder expressed that "the day-to-day work everyone at the different agencies are doing is great but they don't provide long-term policies." This stakeholder discussed that the small-scale activities are beneficial, but the important changes have to be made in the system: "You can buy products at farmers markets but there needs to be policies and programs that make it possible for change to occur at a larger scale."

As stakeholders in the Phoenix area organize to influence food system evolution, making explicit the underlying meanings and objectives of their use of local will likely enhance the prospects of success. It appears that local is being used to refer to more than just food sustainability. It seems to reflect locally embedded interactions focusing on intimate relationships of knowledge and trust. In the IAD framework, these are called the "attributes of community," which form fundamental inputs into any effort to improve governance. As the community moves forward with its plans for food policy, it will be important to open a discussion of what is intended by local and what attributes stakeholders associate with localization. It may be that the desired outcomes of the food system can be achieved by other mechanisms that do not necessarily imply geographic localization (see the discussion in Allen, 2010; Bom \& Purcell, 2006; DeLind, 2011).

In summary, the values, interests, and positions of the interviewed stakeholders suggest that food system assessments at the local level, designed to support food policy coalitions and councils, may benefit from mapping out how stakeholders envision the system that is at the center of food policy work and how specific interventions will result in broader system change. To date, there has been little effort to undertake such formal assessments in preparation for coalition building and food network development; however, the importance of such assessments are featured in a variety of approaches to system transitions and transformations in sustainability research and practice (see, for example, Olsson, Galaz, \& Boonstra, 2014; Smith \& Stirling, 2010). Theory on cross-scalar 
processes of system change highlights the importance of creating experimental spaces, fostering adaptive and reflexive learning, and enabling leadership and transparency (Smith \& Stirling, 2010; Westley et al., 2013).

While food policy coalitions and councils potentially could play such transformative roles, they have tended to be more conservative spaces, focused on programmatic areas of consensus rather than more structural or radical change (Harper et al., 2009; Schiff, 2008). Enhancing the possibilities of coalition influence in change processes may mean expanding coalition membership. Sabatier (1988) posited that advocacy coalitions often need to push to expand system boundaries by engaging stakeholders from outside the key interest groups that form their core constituents in order to acquire additional resources to mobilize change. As the food policy coalition begins its formal work, participants will gain access to new information and create new knowledge; this process will undoubtedly empower some "latent" actors to become more active and involved, potentially altering the nature of coalition strategies (Sabatier, 1988).

\section{Conclusion}

This study aimed to fill a gap in the literature by documenting and identifying the diversity of stakeholder perceptions in the predevelopment stages of forming a "sustainable food system." The nascent efforts to build a food policy coalition in the region are an important first step in bringing together individuals who share a belief system and thus are likely to effectively mobilize for change. As in most publics, and in relation to most sustainability issues, stakeholders move fluidly from critical and subjective assessments of existing problems to idealized notions of what solutions should and could be enacted.

While many of the interviewees aimed for food system transformation - highlighting the inequitable and inefficient national and global structural forces in the food system - their solutions were ultimately focused on "demand restraint" through education and efficiency improvements in the function of the system (Garnett, 2014). Their comments and reflections underscore the ultimate challenge of food system change: on the one hand, there is a recognition and desire for fundamental food system reorganization; on the other, the mechanisms that local stakeholders have available to them are limited in influence by broader-scale institutional structures that govern food system dynamics. It is possible that the efforts of food policy coalitions may be strongest as nodes in larger, regional networks (Sonnino \& Beynon, 2015). By focusing on education, sustainable production, and connectivity in the local food system, such coalitions can build demand for change. As nodes in a national network of local, municipal, and county initiatives, these "action arenas" may provide the foundation for more fundamental structural changes at higher scales- challenging as well as defining the limits of agency and food system boundaries in the process. Over the last decade, a number of national organizations have formed to coordinate communication across locallevel initiatives (e.g., Food Policy Action, the National Sustainable Agriculture Coalition, and the Food Policy Network of John Hopkins University); these national-level groups may become increasingly instrumental in enabling local groups to effect structural change.

It is important to note that, in addition to inadequate education as the biggest barrier to achieving a sustainable food system, a majority of participants also mentioned a lack of communication and/ or collaboration. This result suggests that participants were aware of the fragility of transformative spaces and the importance of building trust in order to build and maintain a movement that is capable of long-lasting change. Food system work can be deeply ideological and emotional for many activists; engaging in formal methods and activities that make diverse perspectives visible for exploration may prove to be increasingly useful for coalition formation. Participatory research and emerging approaches in sustainability science have much to offer in this regard. In addition to the interviews and analysis conducted in this manuscript, with the help of researchers, participants in the initial stages of policy coalition formation can engage in standard approaches such as fuzzy cognitive mapping (e.g., G ray, Zanre, \& G ray, 2014) or Q-methodology 
(e.g., Steelman \& Maguire, 1999) to explore the diversity of perspectives within their emerging networks.

Unsurprisingly, the main areas proposed by the interviewees for initial intervention echoed what they were already doing - building on their individual histories of food system practice, as has been documented in other cases (e.g., Raja et al., 2014). Many argued that these initiatives would need to be inclusive and culturally appropriate, ensuring that all Phoenix residents had equitable access; however, few interviewees had clear ideas on how to achieve this. As in many large metropolitan areas, the growing demographic diversity intersects with divergent needs and values in the food system. Enacting food system change that addresses the underlying social and economic inequities in the food system is challenging. The origins of these structural concerns are often perceived to be beyond local influence; moreover, the solutions that are advocated by food change agents are embedded in socio-cultural assumptions about what is "good" or "right" for oneself and, by extension, others. O nce again, ensuring that diverse sectors in the city can share what sustainability means for them, and why, is essential before sustainability objectives are set.

In summary, this study provides initial insights into the diversity of perspectives and objectives that food policy councils should consider in order to achieve just and sustainable outcomes. The assessment of perspectives and beliefs of food system activists presented in this paper can be used as a baseline assessment from which emergent coalitions of actors can evaluate several factors. These factors include how their membership network has evolved over time in terms of sector representation, perspectives on the causes and appropriate mechanisms for system change, and, importantly, what constitutes the domain of action for intervention. In the case of the now-constituted Maricopa County Coalition, an analysis of participant perspectives could be significant in indicating a convergence in beliefs and strategies. A convergence in beliefs could either be the result of enhanced communication and understanding or, perhaps, a result of the absence- perhaps exclusion - of some of the sectors and associated viewpoints represented in the interviews initially conducted.

This initial exercise in reflective thought can thus lay the groundwork for a dynamic process of learning, innovation, and experimentation for food system solutions at the community level. While most food system assessments that have been completed or are underway in the United States prioritize stakeholder involvement and participation, the framework used here could provide needed structure to initial baseline assessments. This framework can also highlight points of convergence and divergence in perspectives before the challenging work of planning begins.

\section{References}

Allen, P. (2010). Realizing justice in local food systems. C ambridge Journal of Regions, E conomy and Society, 3(2), 295-308. http:/ / doi.org/ 10.1093/ cjres/ rsq015

Barthel, S., Parker, J., \& Ernstson, H. (2013). Food and green space in cities: A resilience lens on gardens and urban environmental movements, U rban Studies, 52(7), 1321-1338. https:/ / doi.org/ 10.1177/ 0042098012472744

Bedore, M. (2014). The convening power of food as growth machine politics: A study of food policymaking and partnership formation in Baltimore. U rban Studies, 51(14), 2979- 2995. https:/ / doi.org/ 10.1177/ 0042098013516685

Bernard, R. H. (1994). Research M ethods in A nthropology (Second Ed.). Plymouth, UK: Altamira Press.

Block, D . R., Chávez, N., Allen, E., \& Ramirez, D . (2012). Food sovereignty, urban food access, and food activism: Contemplating the connections through examples from Chicago. A griaulture and $\mathrm{H}$ uman V alues, 29(2), 203-215. https:/ / doi.org/ 10.1007/ s10460-011-9336-8

Block, D . R., Thompson, M., Euken, J., Liquori, T., Fear, F., \& Baldwin, S. (2008). Engagement for transformation: Value webs for local food system development. A griaulture and $\mathrm{H}$ uman $\mathrm{V}$ alues, 25(3), 379-388. http:// doi.org/ 10.1007/ s10460-008-9113-5

Born, B., \& Purcell, M. (2006). Avoiding the local trap: Scale and food systems in planning research. Journal of Planning E ducation and Research, 26(2), 195-207. https:/ / doi.org/ 10.1177/ 0739456X 06291389 
Cairney, P., \& Heikkila, T. (2014). A comparision of theories of the policy process. In P. Sabatier \& C. Weible (Eds.), Theories of the Policy Process (pp. 363-390). Boulder, C0: Westview Press.

Campbell, M. C. (2004). Building a common table: The role for planning in community food systems. Journal of Planning E ducation and Research, 23(4), 341-355. http:/ / doi.org/ 10.1177/ 0739456X 04264916

Carolan, M. S. (2006). Social change and the adoption and adaptation of knowledge claims: Whose truth do you trust in regard to sustainable agriculture? A griculture and $\mathrm{H}$ uman V alues, 23(3), 325-339. https:/ / doi.org/ 10.1007/ s10460006-9006-4

Colding, J., \& Barthel, S. (2013). The potential of 'Urban G reen Commons' in the resilience building of cities. E cological E onomics, 86, 156-166. https:// doi.org/ 10.1016/ j.ecolecon.2012.10.016

DeLind, L. B. (2011). Are local food and the local food movement taking us where we want to go? Or are we hitching our wagons to the wrong stars? A griaulture and H uman V alues, 28 (2), 273-283. http:// doi.org/ 10.1007/ s10460-010$\underline{9263-0}$

Eakin, H., Connors, J. P., Wharton, C., Bertmann, F., Xiong, A., \& Stoltzfus, J. (2016). Identifying attributes of food system sustainability: Emerging themes and consensus. A griculture and $\mathrm{H}$ uman $\mathrm{V}$ alues, 34(3), 757-773. http:// doi.org/ 10.1007/ s10460-016-9754-8

Ericksen, P. J. (2007). Conceptualizing food systems for global environmental change research. G lobal E nvironmental Change, 18(1), 234-245. http:// doi.org/ 10.1016/ j.gloenvcha.2007.09.002

Ericksen, P., Stewart, B., Eriksen, S., Tschakert, P., Sabates-Wheeler, R., Hansen, J., \& Thornton, P. K. (2010). Adapting food systems. In J. Ingram, P. Ericksen, \& D. Liverman (Eds.), F ood seaurity and global environmental change (pp. 115143). London: Earthscan.

Feenstra, G. (2002). Creating space for sustainable food systems: Lessons from the field. A griculture and $\mathrm{H}$ uman $\mathrm{V}$ alues, 19(2), 99-106. https:/ / doi.org/ 10.1023/ A:1016095421310

Foley, J. A., Ramankutty, N., Brauman, K. A., Cassidy, E. S., Gerber, J. S., Johnston, M., ... Zaks, D. P. M. (2011). Solutions for a cultivated planet. $N$ ature, 478 (7369), 337-342. http:// doi.org/ 10.1038/ nature10452

Garnett, T. (2014). Three perspectives on sustainable food security: efficiency, demand restraint, food system transformation. What role for life cycle assessment? Journal of Cleaner Production, 73, 10-18. http:/ / doi.org/ 10.1016/ j.jclepro.2013.07.045

Godfray, H. C. J., Beddington, J. R., Crute, I. R., Haddad, L., Lawrence, D., Muir, J. F., ... Toulmin, C. (2010). Food security: the challenge of feeding 9 billion people. Scienœ, 327(5967), 812-818. http:// doi.org/ 10.1126/ science.1185383

Gray, S. A., Zanre, E., \& Gray, S. R. J. (2014). Fuzzy Cognitive Maps as Representations of Mental Models and G roup Beliefs. In I. E. Papageorgiou (Ed.), F uzzy C ognitive M aps for A pplied Sciences and E ngineering: F rom F undamentals to E xtensions and L earning A lgorithms. Berlin: Springer.

Grothmann, T., \& Patt, A. (2005). Adaptive capacity and human cognition: The process of individual adaptation to climate change. G lobal E nvironmental C hange, 15(3), 199-213. https:/ / doi.org/ 10.1016/ j.gloenvcha.2005.01.002

Guthman, J. (2003). Fast food/ organic food: Reflexive tastes and the making of 'yuppie chow' Social \& Cultural G eography, 4(1), 45-58. https:/ / doi.org/ 10.1080/ 1464936032000049306

Guthman, J. (2008). Bringing good food to others: Investigating the subjects of alternative food practice. C ultural G eographies, 15(4), 431-447. https:// doi.org/ 10.1177/ 1474474008094315

Harper, A., Alkon, A., Shattuck, A., Holt-G iménez, E., \& Lambrick, F. (2009). F ood policy councils: L essons learned. Food First, Institute for Food and D evelopment Policy. https:/ / foodfirst.org/ wp-content/ uploads/ 2014/ 01/ D R21Food-Policy-Councils-Lessons-Learned-.pdf

Hoey, L., \& Sponseller, A. (2018). "It's hard to be strategic when your hair is on fire": Alternative food movements leaders' motivation and capacity to act. A griculture and $\mathrm{H}$ uman $\mathrm{V}$ alues, 35(3), 595-609. https:// doi.org/ 10.1007/ s10460-018-9850-z

Holloway, L., Cox, R., Kneafsey, M., D owler, E., Venn, L., \& Tuomainen, H. (2010). Are you alternative? Alternative 'food networks and consumers' definitions of alterity. In A. E. G. Jonas \& D. Fuller (Eds.), Interrogating A lterity: A lternative E œnomic and Political Spaœs (pp. 161-173). Farnham, UK: Ashgate. 
Journal of Agriculture, Food Systems, and Community Development

ISSN: 2152-0801 online

https:// www.foodsystemsjournal.org

Holt-Giménez, E., \& Shattuck, A. (2011). Food crisis, food regimes and food movements: Rumblings of reform or tides of transformation? The Journal of Peasant Studies, 38(1), 109-144. https:/ / doi.org/ 10.1080/ 03066150.2010.538578

Horlings, L. G., \& Marsden, T. K. (2011). Towards the real green revolution? Exploring the conceptual dimensions of a new ecological modernisation of agriculture that could "feed the world." G lobal E nvironmental C hange, 21(2), 441452. http:/ / doi.org/ 10.1016/ j.gloenvcha.2011.01.004

Ingram, J., Andersson, J., Bammer, G ., Brown, M., Giller, K., ... Y oung, J. (2010). Engaging stakeholders at the regional level. In J. Ingram, P. Ericksen, \& D . Liverman (Eds.), F ood Security and G lobal E nvironmental Change (p. 169). New York: Earthscan.

Jenkins-Smith, H. C., \& Sabatier, P. A. (1994). Evaluating the advocacy coalition framework. Journal of Public Policy, 14(2), 175-203. https:// doi.org/ 10.1017/ S0143814X 00007431

Kloppenburg, J., Lezberg, S., De Master, K., Stevenson, G. W., \& Hendrickson, J. (2000). Tasting food, tasting sustainability: D efining the attributes of an alternative food system with competent, ordinary people. $\mathrm{H}$ uman O rganization, 59(2), 177-186. https:/ / doi.org/ 10.17730/ humo.59.2.8681677127123543

Marin, A., Ely, A., \& van Zwanenberg, P. (2016). Co-design with aligned and non-aligned knowledge partners: implications for reserach and coproduction in sustainable food systems. C urrent 0 pinion in E nvironmental Sustainability, 20, 93-98. https:// doi.org/ 10.1016/ j.cosust.2016.09.003

Miller, T. R., Wiek, A., Sarewitz, D., Robinson, J., Olsson, L., Kriebel, D ., \& Loorbach, D . (2014). The future of sustainability science: A solutions-oriented research agenda. Sustainability Scienœ, 9(2), 239-246. https:// doi.org/ 10.1007/ s11625-013-0224-6

Olsson, P., G alaz, V., \& Boonstra, W. J. (2014). Sustainability transformations: A resilience perspective. E ology and Society, 19(4), 1. https:/ / doi.org/ 10.5751/ ES-06799-190401

O strom, E. (2007). A diagnostic approach for ongoing beyond panaceas. Proceedings of the N ational A cademy of Scienos, 104(39), 15181-15187. https:// doi.org/ 10.1073/ pnas.0702288104

O strom, E. (2011). Background on the Institutional Analysis and D evelopment Framework. Policy Studies Journal, 39(1), 7-27. https:// doi.org/ 10.1111/ j.1541-0072.2010.00394.x

Pothukuchi, K. (2004). Community food assessment: A first step in planning for community food security. Journal of Planning E ducation and Research, 23(4), 356-377. http:/ / doi.org/ 10.1177/ 0739456X 04264908

Pothukuchi, K., \& Kaufman, J. L. (1999). Placing the food system on the urban agenda: The role of municipal institutions in food systems planning. A griaulture and $\mathrm{H}$ uman $\mathrm{V}$ alues, 16(2), 213-224. http:/ / doi.org/ 10.1023/ A:1007558805953

Poulsen, M. N., \& Spiker, M. L. (2014). Integrating urban farms into the social landscape of cities: Recommendations for strengthening the relationship between urban farms and local communities. Johns Hopkins Bloomberg School of Public Health. Retrieved from https:/ / www.jhsph.edu/ research/ centers-and-institutes/johns-hopkins-center-for-a-livablefuture/ pdf/ projects/ urban-soil-safety/ Community\%20buyin\%20for\% 20urban\%20farms July2014 Full\%20report.pdf

Raja, S., Picard, D ., Baek, S., \& D elgado, C. (2014). Rustbelt radicalism: A decade of food systems planning in Buffalo, New York (USA). Journal of A griculture, F ood Systems, and Community D evelopment, 4(4), 173-189. http:// dx.doi.org/ 10.5304/ jafscd.2014.044.015

Reed, M. S., Graves, A., D andy, N., Posthumus, H., Hubacek, K., Morris, J., ... Stringer, L. C. (2009). Who's in and why? A typology of stakeholder analysis methods for natural resource management. Journal of E nvironmental M anagement, 90(5), 1933-1949. https:// doi.org/ 10.1016/ j.jenvman.2009.01.001

Sabatier, P. A. (1988). An advocacy coalition framework of policy change and the role of policy-oriented learning therein. Policy Sciences, 21(2-3), 129-168. https:/ / doi.org/ 10.1007/ BF00136406

Scherb, A., Palmer, A., Frattaroli, S., \& Pollack, K. (2012). Exploring food system policy: A survey of food policy councils in the United States. Journal of A griaulture, F ood Systems, and C ommunity D evelopment, 2(4), 3-14. http:/ / dx.doi.org/ 10.5304/ jafscd.2012.024.007

Schiff, R. (2008). The role of food policy councils in developing sustainable food systems. Journal of $H$ unger \& E nvironmental N utrition, 3(2-3), 206-228. https:/ / doi.org/ 10.1080/ 19320240802244017 
Slocum, R. (2006). Whiteness, space and alternative food practice. G eoforum, 38(3), 520-533. https:// doi.org/ 10.1016/j.geoforum.2006.10.006

Smith, A., \& Stirling, A. (2010). The politics of social-ecological resilience and sustainable socio-technical transitions. E ology and Society, 15(1), 11. https:/ / doi.org/ 10.5751/ ES-03218-150111

Sonnino, R., \& Beynon, B. (2015) Rethinking food governance: Urban innovations. In M. D eakin, D . Kiamantini, \& N. Borelli (Eds.), The G overnanœ of City F ood Systems. Milan: Fondazione Giangiacomo Feltrinelli Press.

Spangenberg, J. H. (2011). Sustainability science: A review, an analysis and some empirical lessons. E nvironmental Conservation, 38(3), 275-287. https:/ / doi.org/ 10.1017/ S0376892911000270

Steelman, T. A., \& Maguire, L. A. (1999). Understanding participant perspectives: Q-methodology in national forest management. Journal of Policy A nalysis and Management, 18(3), 361-388. https:// doi.org/ 10.1002/ (SICI)15206688(199922)18:3<361::AID-PAM3>3.0.CO;2-K

Tilman, D., Cassman, K. G., Matson, P. A, Naylor, R., \& Polasky, S. (2002). Agricultural sustainability and intensive production practices. N ature, 418(6898), 671-677. http:/ / doi.org/ 10.1038/ nature01014

van Kerkhoff, L., \& Lebel, L. (2006). Linking knowledge and action for sustainable development. A nnual Review of E nvironment and Resources, 31(1), 445-477. http:// doi.org/ 10.1146/ annurev.energy.31.102405.170850

Westley, F. R., Tjornbo, O., Schultz, L., Olsson, P., Folke, C., Crona, B., \& Bodin, Ö. (2013). A theory of transformative agency in linked social-ecological systems. E ology and Society, 18(3), 27. https:/ / doi.org/ 10.5751/ ES-05072-180327

Winter, M. (2003). Embeddedness, the new food economy and defensive localism. Journal of Rural Studies, 19(1), 23-32. https:// doi.org/ 10.1016/ S0743-0167(02)00053-0 